Article

\title{
The Best Bang for the Bucks: Rethinking Global Investment in Biodiversity Conservation
}

\author{
Sebastián Cordero ${ }^{1, *}$, Gabriel J. Castaño-Villa ${ }^{2,3}$ and Francisco E. Fontúrbel ${ }^{1}$ (i) \\ 1 Instituto de Biología, Facultad de Ciencias, Pontificia Universidad Católica de Valparaíso, \\ Av. Universidad 330, Valparaíso 2373223, Chile; fonturbel@gmail.com \\ 2 Grupo de Investigación en Ecosistemas Tropicales, Facultad de Ciencias Exactas y Naturales, \\ Universidad de Caldas, C. 65 \# 26-10, Manizales 170004, Colombia; gabriel.castano_v@ucaldas.edu.co \\ 3 Departamento de Desarrollo Rural y Recursos Naturales, Facultad de Ciencias Agropecuarias, \\ Universidad de Caldas, C. 65 \# 26-10, Manizales 170004, Colombia \\ * Correspondence: sebastian.cordero@pucv.cl
}

Received: 14 October 2020; Accepted: 2 November 2020; Published: 6 November 2020

check for updates

\begin{abstract}
Biodiversity loss is a central issue in conservation biology, with protected areas being the primary approach to stop biodiversity loss. However, education has been identified as an important factor in this regard. Based on a database of threatened species and socio-economic features for 138 countries, we tested whether more protected areas or more education investment is associated with a lower proportion of threatened species (for different groups of vertebrates and plants). For this, we fitted generalized linear mixed-effects models (GLMM) to assess the relative importance of socio-economic variables on the proportion of threatened species. We found that education investment was negatively associated with the proportion of threatened species in 2007 and 2017, as well as with their change rates. Conversely, the percentage of protected land was significant for reptiles but showed weak relationships with other groups. Our results suggest that only increasing protected areas will not stop or reduce biodiversity loss, as the context and people's attitudes towards wildlife also play major roles here. Therefore, investing in education, in addition to protected areas, would have the missing positive effect on achieving effective species conservation actions worldwide.
\end{abstract}

Keywords: education; islands; long-term effects; protected areas; urbanization; threatened species

\section{Introduction}

Biodiversity loss is the most central issue in conservation biology. As a result of human actions, hundreds of species have gone extinct during the last few centuries [1], and hundreds more are likely to be extinct in the short term. In response to this global problem, the United Nations created the Convention on Biological Diversity (CBD) in 1992, seeking a multi-lateral agreement to achieve sustainable development and stop biodiversity loss [2]. Since then, we have acknowledged that the solution to stop biodiversity loss not only relies on the academy and scientific knowledge but also on social and economic factors [3]. Therefore, a multi-dimensional approach is needed to deal with the biodiversity loss crisis at both local and global scales [4]. In this regard, the United Nations 2030 Agenda for Sustainable Development points to education and protected areas as key instruments to reduce biodiversity loss and improve people's quality of life.

Most countries in the world have improved and expanded their protected area systems in order to slow biodiversity loss and create conservation spaces in which the extant biodiversity can be spared $[5,6]$. However, the effectiveness of protected areas is largely debated [7-9]. The increase of protected area extent across countries seems not to be enough to reduce biodiversity loss. Those spare lands intended as biodiversity preservation spaces are not independent of their context (i.e., many protected areas 
are surrounded by a heterogeneous matrix of disturbed lands), sometimes are not large enough, and in many cases are not representative enough [10,11]. As protected surface increases, the human population, urban areas, and the percentage of the human population living in cities also increases [12], posing a major threat to the biodiversity outside protected area borders $[13,14]$.

An important issue within the socio-economic dimension of biodiversity conservation is education. In this regard, a lack of conservation opportunities is associated with poor education in countries within biodiversity hotspots [15]. Education (and particularly education quality) is acknowledged as a key (but not quite evident) factor determining positive attitudes towards biodiversity [16]. Therefore, education for conservation is amongst the top objectives of conservation biology as it could be the necessary force to achieve long-term societal changes, making attitudes to nature more positive [17].

Several international agendas for biological conservation have emerged during the last decades, aiming at knowledge and valuation of biodiversity based on environmental education [18,19]. Citizens with environmental education can take action in favor of biodiversity. Thus, a special focus has been placed on the younger generations [20]. However, despite the great relevance of education for biodiversity conservation, many goals pursued have not yet been achieved, mainly because education interacts with different socio-economic and biological factors that have not been appropriately addressed [21].

Here, we present a global assessment of the relative importance of protected areas and education investment for the proportion of threatened vertebrate and plant species. Based on socio-economic and biological information from 138 countries from the seven continents (Africa, Asia, Australia, Europe, Central America, North America, South America), we assessed the relative importance of protected areas and education (which are two major investment sectors for biodiversity conservation) for explaining the proportion of threatened species in 2007 and 2017, as well as the change in threat levels in these ten years. We tested the following hypotheses: (1) if protected areas are sufficient by themselves, larger protected area surfaces and larger proportions of land spared as protected lands should be associated with lower proportions of threatened species; (2) more investment in education should generate positive attitudes towards biodiversity, and, therefore, we expect lower proportions of threatened species in those countries investing more money in education.

\section{Materials and Methods}

\subsection{Data Sources}

We built two datasets. The first dataset contains information regarding the proportion of threatened species of terrestrial vertebrates (i.e., amphibians, reptiles, birds, mammals, and all combined) and plants for two time periods: 2007 and 2017. We obtained the number of species per group present in each country from the following databases: eBird 2017 edition (https://ebird.org) and Avibase 2017 edition (https://avibase.bsc-eoc.org) for birds, the Reptile Database 2017 edition (http://reptile-database.reptarium.cz/) for reptiles, Amphibians Species of the World [22] for amphibians, Mammal Species of the World [23], and the Guide to Standard Floras of the World [24] for vascular plants, supplemented with regional databases for countries not included in the list. Additionally, we obtained the number of threatened species per group from the International Union for Conservation of Nature (IUCN) red list database (http://www.iucnredlist.org).

The second dataset contains socio-economic information for each country (Table S1), composed by the following variables: geography (mainland or island), country size (in $\mathrm{km}^{2}$ ), population size, population density (hab./ $\mathrm{km}^{2}$ ), urbanization (\% of the country area corresponding to urban areas), gross domestic product (GDP hereafter, expressed in M USD), \% of GDP invested in education, USD invested in education (resulting from the multiplication of the last two variables), protected area extent $\left(\mathrm{km}^{2}\right)$, and the $\%$ of the country designed as a protected area (resulting from dividing protected area surface by country size $\times 100 \%$ ). 
We selected those variables as they represent most of the aspects of human actions over native flora and fauna. We expect population features, such as size and density, to have negative effects on biodiversity, as they directly influence the impact that humans exert on the landscape and the extinction of species [25]. Therefore, we consider country size to make population density values comparable between countries, as well as geography since islands and the mainland are subject to different levels of anthropogenic impact and extinction dynamics [26]. Similarly, the impacts of urbanization are assumed to have an overall detrimental effect on biodiversity, which is also strongly related to the size and density of human populations [27-29]. Further, since socio-economic aspects, such as educational level and income, also modulate people's interaction with the environment [30,31], we included the following variables: GDP, \% of the GDP invested in education, and USD invested in education. On the other hand, a greater protected area extent is expected to be more effective in conserving biodiversity $[7,32]$. Thus, to make the extent of protected areas comparable between countries of different sizes, we also include the proportion of the country designated as a protected area.

We obtained country information (data from 2006) from the CIA Factbook website (https://www.cia.gov/library/publications/the-world-factbook/). Although there is updated information, we used the 2006 dataset to account for the time lag in education effects (i.e., the effects of investing in education are not immediate). Attitudinal changes towards biodiversity can take several years and are expected to be observed specially in younger generations since the implementation of environmental education is key at an early age [20]. We gathered information for 138 countries across the world (we did not include countries with incomplete information).

\subsection{Data Analysis}

First, we conducted a correlation analysis among the socio-economic variables (Figure S1) in order to detect highly correlated and potentially multicollinear variables, aiming to avoid variable redundancy in the models. Then, we transformed the proportion of threatened species for each group and year using Equation (1):

$$
\log \left(\frac{p}{1-p}\right)
$$

We transformed the percentage of protected area per country using $\log (p+1)$. We used these transformations to improve the data following a Gaussian distribution.

We fitted generalized linear mixed-effects models [33], using the proportion of threatened species as the response variable. We included the following socio-economic variables as predictors (after filtering for redundant variables): \% of GDP invested in education, protected surface, and \% of protected area. We included urbanization and population density as covariates (in order to account for major differences among countries). Geography (mainland or island) was included as a random factor to account for geographic variability, as islands tend to have higher threat levels than mainland countries due to their biogeographic context [26]. Generalized linear mixed-effects model (GLMM) parameters and their significance were estimated using restricted maximum likelihood $t$-tests with a Kenward-Roger approximation to degrees of freedom [34]. Then, we used multi-model inferences [35] to assess the relative importance of each predictor variable within the GLMM models fitted. For this, we obtained the delta $\leq 2$ model subset based on the Bayesian information criterion (BIC) rank. The resulting bar plot represents the percentage of models of the $\triangle \mathrm{BIC} \leq 2$ subset in which each predictor variable occurs, ordered from the most important to the least [35]. We used this procedure to examine the 2007 and 2017 datasets and also to examine the change between 2017 and 2007 (i.e., creating new response variables from the difference between the 2017 and 2007 datasets).

Then, to examine the significance of the change in threatened species proportion between 2007 and 2017, we used paired $t$-tests for each group. Finally, we contrasted our 2006 protected area percentages per country with the most recent data from the World Database on Protected Areas (WDPA, www.protectedplanet.net, updated June 2019) to estimate the increase in protected area coverage in each country between 2006 and 2019, aiming to relate such increases to the change in 
threatened species proportions. All analyses were conducted in R 3.5.1 [36], using the packages mgcv [37], lme4 [38], lmerTest [39], pbkrtest [34], and MuMIn [40].

\subsection{Data Accessibility}

Species and full socio-economic databases, the R code used, and its detailed outputs are available from the figshare digital repository (doi:10.6084/m9.figshare.9171992).

\section{Results}

\subsection{Effects of Socio-Economic Variables on the Proportion of Threatened Species}

We found for 2007 that education investment was significant for all vertebrates combined (and particularly for reptiles and amphibians), while for birds and mammals it was not significant, showing that countries that invest more money (i.e., a more significant percentage of GDP) have lower proportions of threatened species. Conversely, the percentage of protected land was significant only for reptiles, and the protected surface was significant for birds. However, this relationship is positive, suggesting that countries with more protected areas also have more threatened bird species (Table 1a). Examining the 2017 dataset, education presented significant effects on vertebrates (and particularly on mammals and reptiles) and plants, showing that more investment in education is associated with fewer threatened species. The percentage of protected land was significant for mammals, reptiles, and all vertebrates, whereas the protected surface was significant for birds but with a positive relationship, as in 2007 (Table 1b). In all cases, the proportion of threatened species is reduced with education investment and the percentage of protected land, but it increases with protected surface, particularly for birds. Examining the relative importance of the socio-economic variables, we found that education investment is the most important predictor in all cases, with support values ranging between $50 \%$ and $100 \%$. The next variable in importance is the percentage of protected land, which was important for birds, reptiles, and amphibians. Protected surface and population density were the least important variables in all cases (Figure S2).

Table 1. Summary of the effects of socio-economic predictors on the proportion of threatened species in 2007, 2017, and the change between 2007 and 2017. For each, case $t$-values and their significance are presented (ns $=p>0.10 ; \dagger=0.05<p<0.10,{ }^{*}=p<0.05,{ }^{* *} p<0.01,{ }^{* * *}=p<0.001$ ).

\begin{tabular}{|c|c|c|c|c|c|c|}
\hline Predictor & Amphibians & Reptiles & Birds & Mammals & Vertebrates & Plants \\
\hline \multicolumn{7}{|c|}{ a. 2007 threatened species data } \\
\hline Education & $-31.610 *$ & $-33.100 * *$ & $-0.121^{\mathrm{ns}}$ & $-3.702^{\mathrm{ns}}$ & $-9.027^{* *}$ & $-11.937^{\dagger}$ \\
\hline$\%$ prot. area & $0.014^{\mathrm{ns}}$ & $-0.685^{*}$ & $-0.104^{\mathrm{ns}}$ & $-0.096^{\mathrm{ns}}$ & $-0.108^{\mathrm{ns}}$ & $0.029 \mathrm{~ns}$ \\
\hline Prot. surface & $0.001 \mathrm{~ns}$ & $0.001^{\mathrm{ns}}$ & $0.002 *$ & $0.001 \mathrm{~ns}$ & $0.001^{\dagger}$ & $0.001^{\mathrm{ns}}$ \\
\hline Urbanization & $-1.763^{\mathrm{ns}}$ & $0.396^{\mathrm{ns}}$ & $0.0050^{\mathrm{ns}}$ & $0.202^{\mathrm{ns}}$ & $0.013^{\mathrm{ns}}$ & $-1.216^{\mathrm{ns}}$ \\
\hline Pop. density & $-0.001 \mathrm{~ns}$ & $0.001^{\mathrm{ns}}$ & $0.001^{\mathrm{ns}}$ & $-0.001^{\mathrm{ns}}$ & $-0.002^{\dagger}$ & $0.001^{\mathrm{ns}}$ \\
\hline \multicolumn{7}{|c|}{ b. 2017 threatened species data } \\
\hline Education & $-31.070^{\dagger}$ & $-40.910^{* * *}$ & $-4.546^{\dagger}$ & $-8.769 * *$ & $-12.260 * * *$ & $-30.640 * *$ \\
\hline$\%$ prot. area & $0.039 \mathrm{~ns}$ & $-0.841^{* * *}$ & $-0.005^{\mathrm{ns}}$ & $-0.226^{* *}$ & $-0.196^{* *}$ & $-0.001^{\mathrm{ns}}$ \\
\hline Prot. surface & $0.001^{\mathrm{ns}}$ & $0.001^{\dagger}$ & $0.001^{* *}$ & $0.001^{\mathrm{ns}}$ & $0.001^{+}$ & $0.001^{\mathrm{ns}}$ \\
\hline Urbanization & $-1.026^{\mathrm{ns}}$ & $-0.517^{\mathrm{ns}}$ & $0.111^{\mathrm{ns}}$ & $-0.560^{\dagger}$ & $-0.137^{\mathrm{ns}}$ & $-0.252^{\mathrm{ns}}$ \\
\hline Pop. density & $-0.001^{\mathrm{ns}}$ & $-0.001^{\mathrm{ns}}$ & $-0.001^{\mathrm{ns}}$ & $0.001^{\mathrm{ns}}$ & $-0.001^{\mathrm{ns}}$ & $0.001^{\mathrm{ns}}$ \\
\hline \multicolumn{7}{|c|}{ c. Change between 2007 and 2017} \\
\hline Education & $-26.020^{\mathrm{ns}}$ & $-43.650 *$ & $1.118^{\mathrm{ns}}$ & $-37.290^{\mathrm{ns}}$ & $-25.890 *$ & $-6.605 *$ \\
\hline$\%$ prot. area & $-0.147^{\mathrm{ns}}$ & $-1.256^{* *}$ & $0.043^{\mathrm{ns}}$ & $-0.971^{+}$ & $-0.549 *$ & $-0.007^{\mathrm{ns}}$ \\
\hline Prot. surface & $-0.001^{\mathrm{ns}}$ & $0.001^{\mathrm{ns}}$ & $-0.001^{\dagger}$ & $0.001^{\mathrm{ns}}$ & $0.001^{\mathrm{ns}}$ & $0.001^{\mathrm{ns}}$ \\
\hline Urbanization & $1.719^{\mathrm{ns}}$ & $-1.661^{\mathrm{ns}}$ & $-0.163^{\mathrm{ns}}$ & $-6.218 * *$ & -1.439 ns & $-0.162^{\mathrm{ns}}$ \\
\hline Pop. density & $-0.001 \mathrm{~ns}$ & $-0.002 *$ & $-0.001^{\mathrm{ns}}$ & $0.001^{\mathrm{ns}}$ & $-0.001^{\mathrm{ns}}$ & $-0.001^{\mathrm{ns}}$ \\
\hline
\end{tabular}




\subsection{Proportion of Threatened Species between 2007 and 2017}

Comparing the proportion of threatened species between 2007 and 2017, we found that the proportion of threatened mammals was not significantly different. However, the proportion of threatened birds, reptiles, amphibians, total vertebrates, and plants significantly increased in these ten years (Table 2). Mammals, reptiles, and amphibians had the largest variation ranges, with contrasting changes across countries. Regarding the effects of socio-economic variables on the change rates, education was significant for vertebrates (mainly reptiles) and plants. In contrast, the proportion of protected areas was significant for vertebrates and particularly reptiles (Table 1c). Examining the relative importance of these variables for the change of threatened species proportion, education had the largest support across the models, followed by the percentage of protected land, which was important for reptiles and amphibians (Figure S3).

Table 2. Comparison of the proportion of threatened species of mammals, birds, reptiles, amphibians, all vertebrates, and plants between 2007 and 2017, change rate $(\Delta=2017-2007)$ and variation range (minimum and maximum change values). We assessed statistical differences using a paired $t$-test (two-tailed).

\begin{tabular}{lccccccc}
\hline Comparison & $\mathbf{\%} \mathbf{2 0 0 7}$ & $\mathbf{\%} \mathbf{2 0 1 7}$ & Change & Range & $\boldsymbol{t}$ & $\mathbf{d f}$ & $\boldsymbol{p}$ \\
\hline Amphibians & $9.76 \%$ & $10.58 \%$ & $0.83 \%$ & -11 to $27 \%$ & -2.417 & 137 & 0.017 \\
Reptiles & $4.19 \%$ & $7.53 \%$ & $3.32 \%$ & -8 to $33 \%$ & -6.503 & 137 & $<0.001$ \\
Birds & $2.61 \%$ & $3.67 \%$ & $1.00 \%$ & -1 to $4 \%$ & -18.545 & 137 & $<0.001$ \\
Mammals & $10.74 \%$ & $11.49 \%$ & $0.72 \%$ & -7 to $44 \%$ & -1.500 & 137 & 0.136 \\
Vertebrates & $6.85 \%$ & $8.33 \%$ & $1.49 \%$ & -3 to $25 \%$ & -5.731 & 137 & $<0.001$ \\
Plants & $0.79 \%$ & $1.17 \%$ & $0.28 \%$ & 0 to $4 \%$ & -6.339 & 136 & $<0.001$ \\
\hline
\end{tabular}

Examining changes in threatened species proportions between 2007 and 2017, we found that all groups assessed here experienced an increase in the proportion of threatened species between 2007 and 2017 (Table S2). However, in some cases, the differences among countries are considerable (for example, change rates for mammals range from $-7 \%$ to $44 \%$ ). Contrasting those rate changes to our socio-economic variables, we found that countries investing more resources in education (expressed as the percentage of the GDP invested in education in 2006, with ten years of time lag), have lower or even negative change rates over these ten years. This pattern was consistent across groups, except for birds (cf. Figure 1).

Then, examining the relationship with the percentage of protected land, we found weak relationships in all cases (Figure S4). Finally, examining the relationship between the change of threatened species between 2007 and 2017 and the increase in protected area surface between 2006 and 2019, we observe contrasting results among groups (cf. Figure 2). However, none of those relationships was statistically significant (Table S3). 

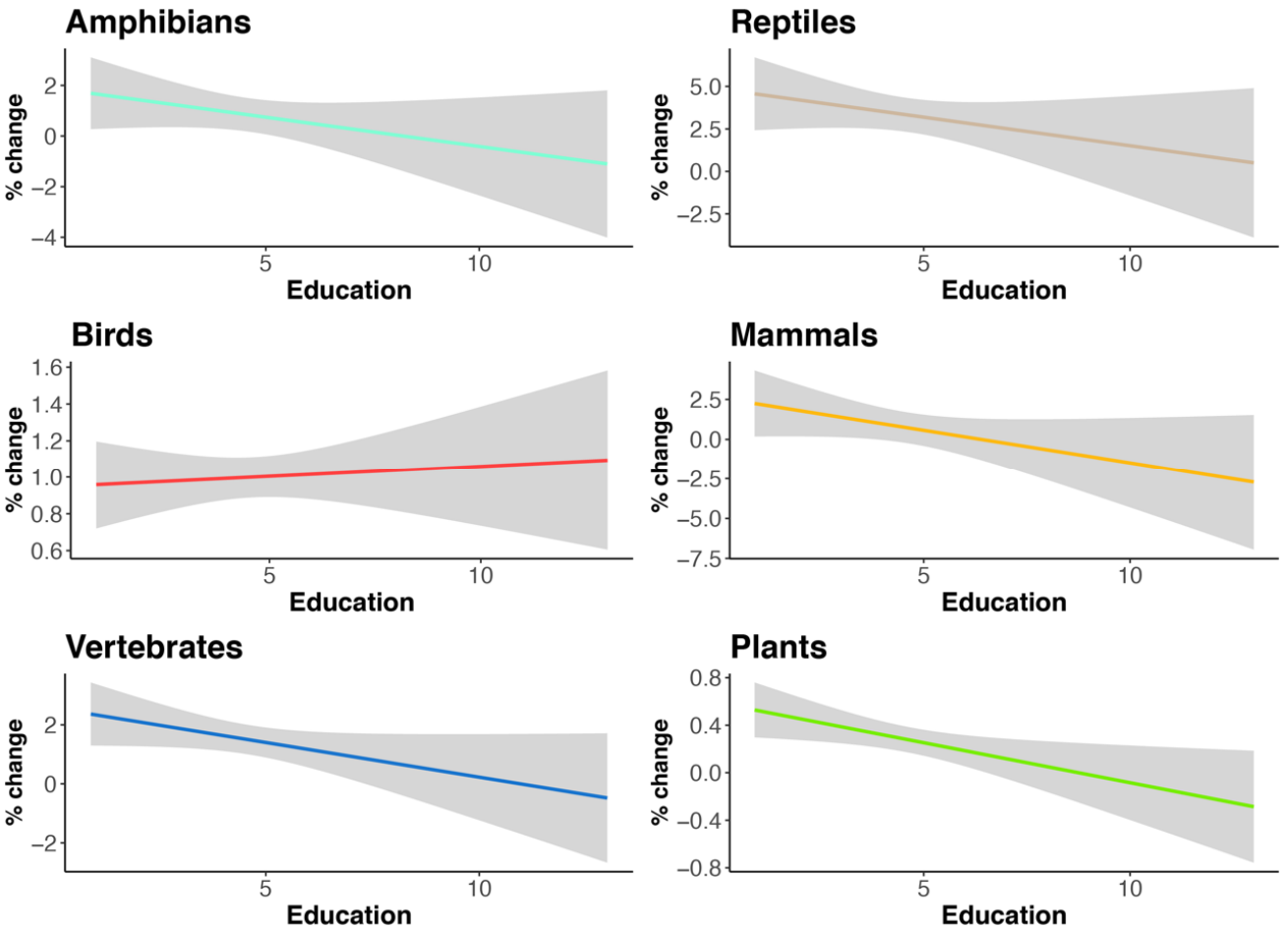

Figure 1. Relationships between education investment (expressed as the percentage of GDP invested in education) and the change in the proportion of threatened species between 2017 and 2007. Gray areas represent the $95 \%$ confidence interval.
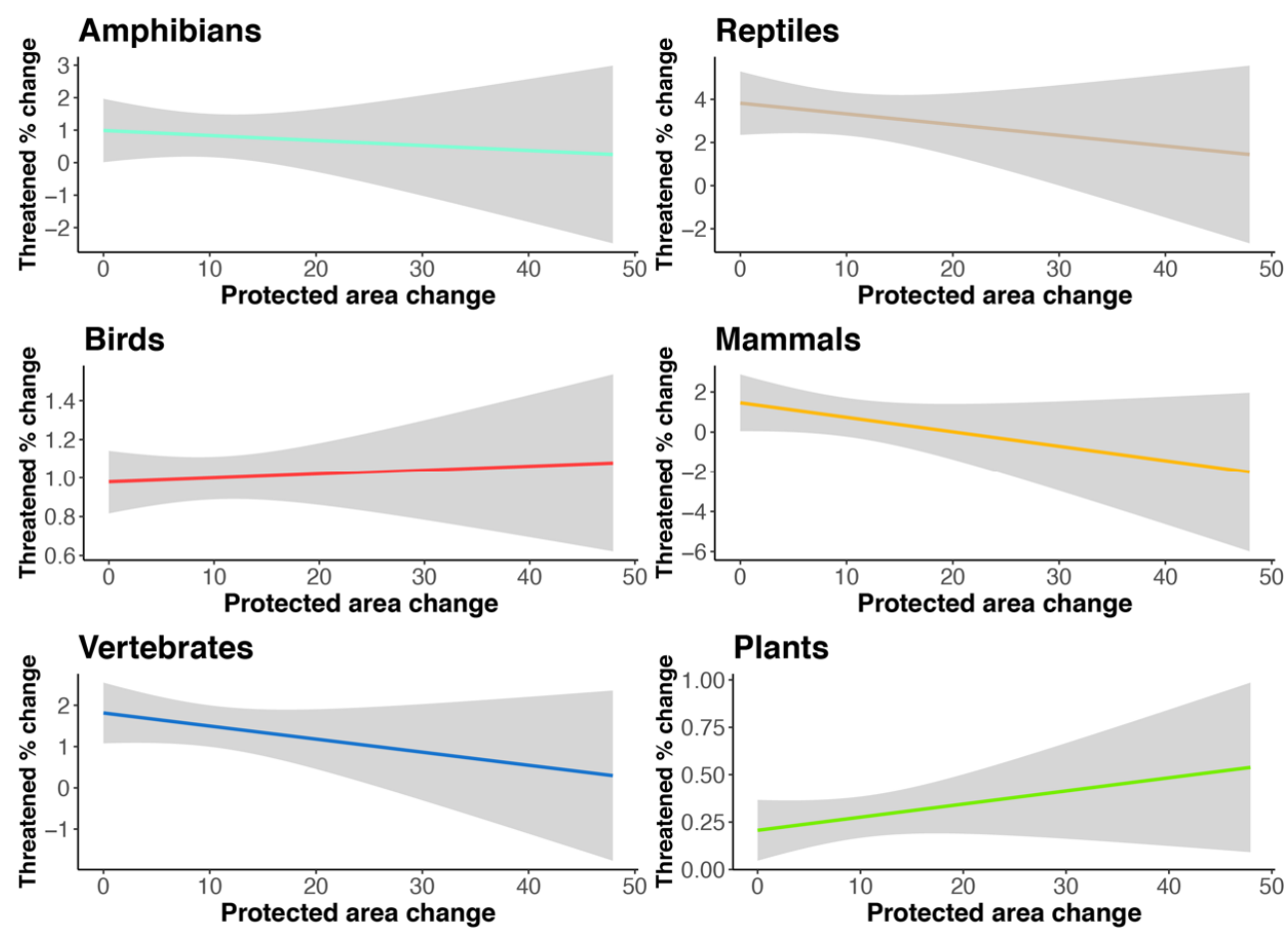

Figure 2. Relationships between protected area increase between 2006 and 2019 (based on the percentage of each country designated as protected area) and the change in the proportion of threatened species between 2017 and 2007. Gray areas represent the 95\% confidence interval. 


\section{Discussion}

Our results point out that investment in education can be as crucial as sparing land as protected area for wildlife conservation. Those countries investing more money in education (see Figure S5 and Figure S6) consistently had lower proportions of threatened vertebrates and plants. The most substantial result of our assessment is the significant effect of education investment on the proportion of threatened vertebrate and plant species, as well as on their change in ten years. Thus, education plays a central role in biodiversity conservation as it generates positive attitudes towards wildlife [16], empowers people, and, with the appropriate information, encourages them to take action. Such attitude changes are essential to change the conservation paradigm and to achieve changes in the long-term $[17,41]$. Countries that invest larger proportions of their GDP (irrespective of the amount of such GDP) in education may have more opportunities to achieve attitude changes in the population. This outcome is evident from our dataset as the money invested in education in 2006 showed a favorable effect on threatened species in 2017. Educative processes involve changes in the mid- and long-term, as the resources invested now to improve education quality will show their effects in a decade or more as a result of a progressive attitude change (particularly among children and young people), as the Sustainable Development 2030 Agenda proposes. Despite their importance for conservation practice, protected areas alone have a limited effect on relieving biodiversity loss. Designating protected areas is not only a scientific process as it also involves political decisions. Therefore, the weak effect of increasing protected areas on reducing the proportion of threatened species could be related to the common practice of protecting marginal lands instead of high priority areas [10,42]. For example, Chile has protected $\sim 22 \%$ of its territory, but $89 \%$ of those protected areas are located in latitudes $>43^{\circ} \mathrm{S}$, resulting in an uneven distribution of the area under protection regime [10], leaving many conservation-concerned and highly threatened taxa unprotected [42]. In this example, most of the threatened and endemic species, along with specialized ecological interactions, occur in the Mediterranean-type ecosystem of central Chile [43], which has the lowest protected area coverage and also is highly threatened by the expansion of urban areas, vineyards, and avocado plantations. If we examine this pattern at the global scale, we observe a moderate correspondence of protected areas with biodiversity hotspots (Figure 3), which is even lower when we examine threatened species instead (Figure 4). For example, the Brazilian Atlantic Rainforest, the Indian Peninsula, and the Southeast Asian archipelago have the largest proportions of threatened birds, but protected areas are negligible at those locations [44-46]. A similar pattern is observed for mammals of Southeast Asia and amphibians of Eastern China. From the keystone work of Margules and Pressey [47], systematic conservation planning has oriented decision-making regarding protected areas. In this regard, protected areas alone are not enough to dampen biodiversity loss as their success depends on landscape and socio-economic contexts, which should also be taken into account.

In addition, the exponential increase of the human population and its rapid concentration in urban areas are strong drivers of biodiversity loss [12]. We included population density and urbanization as covariates in our models because they have a negative correlation with biodiversity across taxonomic groups but are particularly critical for reptiles and amphibians [28,50]. On the other hand, plant diversity is also negatively affected by urbanization and population densification [51], which exert adverse impacts on the structure and composition of plant communities, leading to the extinction of native plants and the spread of invasive species [52]. These impacts can trigger a cascade effect on biodiversity loss since the loss of plant species usually results in the loss of mammal species associated with the structural features of vegetation [53]. Large mammals, in particular, are expected to be severely affected by urbanization as they require large habitat extensions, which become a limited resource as a result of urbanization processes [53] and are the primary target of protected area-based conservation. In any case, native populations tend to be reduced under extreme urbanization conditions, irrespective of the taxonomic group [53]. 
(a) Amphibian diversity

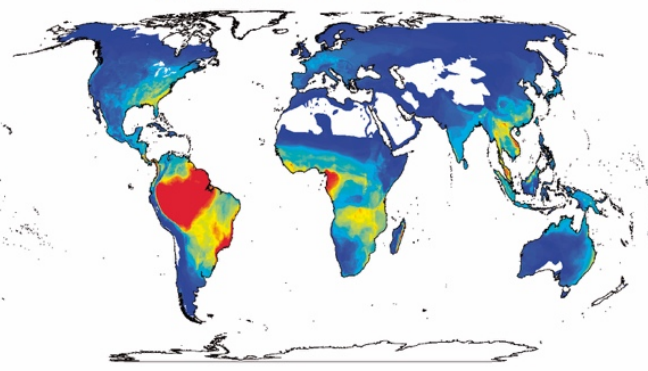

(c) Mammal diversity (b) Bird diversity

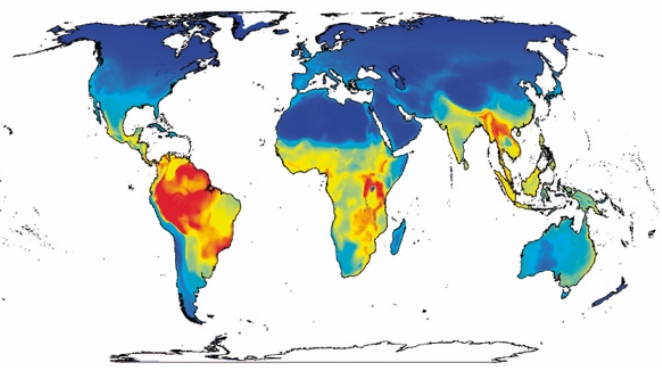

(d) Protected areas
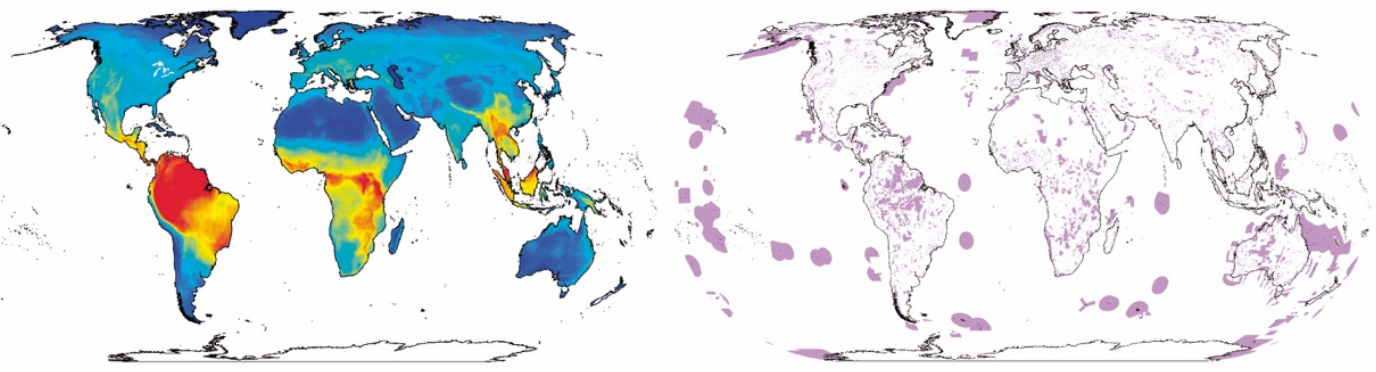

Figure 3. Global species richness of (a) amphibians, (b) birds, and (c) mammals. World protected areas are shown in panel (d). Diversity data were obtained from $[48,49]$. Protected area data were obtained from the World Database on Protected Areas (WDPA, www.protectedplanet.net, updated June 2019).

(a) Threatened amphibians

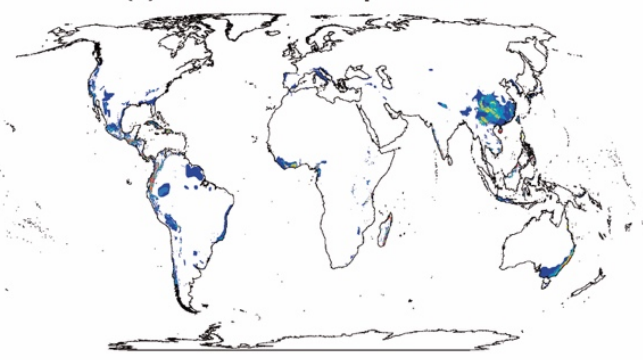

(c) Threatened mammals

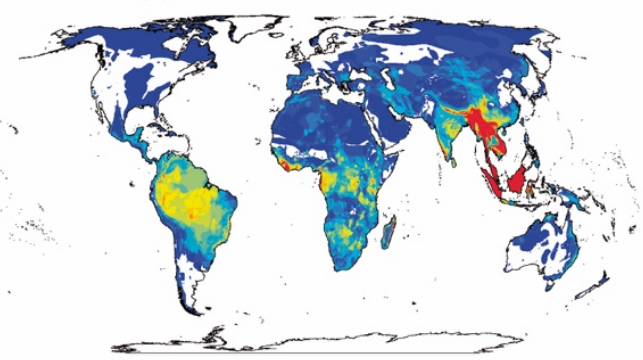

(b) Threatened birds

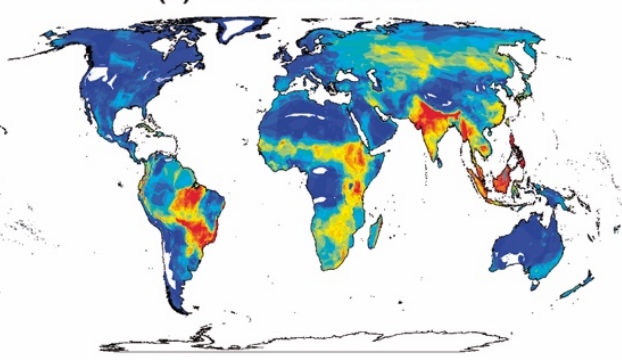

(d) Protected areas

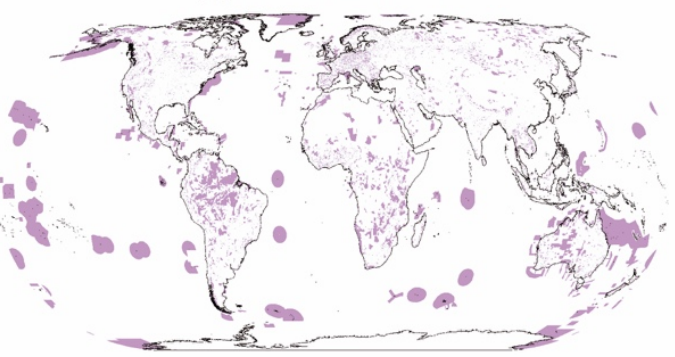

Figure 4. Globally threatened species of (a) amphibians, (b) birds, and (c) mammals. World protected areas are shown in panel (d). Diversity data were obtained from $[48,49]$. Protected area data were obtained from the World Database on Protected Areas (WDPA, www.protectedplanet.net, updated June 2019).

\section{Conclusions}

Stopping biodiversity loss is a complex and challenging task that requires a multi-dimensional approach. Our results point to education as the primary change force that can trigger a long-term attitudinal change towards wildlife and its conservation. Without people's involvement, any other 
effort may have limited success. Even though protected areas comprise about $12 \%$ of the terrestrial surface, global biodiversity continues progressively declining [6]. Those protected areas are suffering biodiversity erosion processes as a result of habitat disturbance, hunting, defaunation, and overexploitation [54], which are directly related to people's attitudes and their access to information. Despite protected areas being effective, avoiding deforestation within their boundaries, what happens outside them largely depends on people's attitudes, and those attitudes are ultimately influenced by education. Protected areas are essential for biodiversity conservation without a doubt [55], but we cannot rely only on them. We urge a paradigm change not only prioritizing high diversity areas, but also shifting to an integrative framework beyond protected areas, including areas with endangered/endemic species, along with adequately representing the diversity of the ecosystems, including the people, and controlling the rapid expansion of urban settlements in natural areas with high-level policies.

Supplementary Materials: The following are available online at http://www.mdpi.com/2071-1050/12/21/9252/s1: Figure S1: Correlation matrix among socio-economic variables; Figure S2 and Figure S3: Relative importance of the variables included in the GLMM models; Figure S4: Relationships between protected land and change in threatened species; Table S1: List of the countries included in the assessment; Table S2: Changes in threatened species proportions between 2007 and 2017; Table S3: Detailed GLMM results of the relationship between the percentage of threatened species and the increase in protected areas.

Author Contributions: Conceptualization, F.E.F. and G.J.C.-V.; methodology, S.C., G.J.C.-V., and F.E.F.; software, S.C. and F.E.F.; validation, S.C. and F.E.F.; formal analysis, S.C. and F.E.F.; investigation, S.C., G.J.C.-V., and F.E.F.; data curation, S.C. and F.E.F.; writing-original draft preparation, S.C., G.J.C.-V., and F.E.F.; writing-review and editing, S.C. and F.E.F. All authors have read and agreed to the published version of the manuscript.

Funding: This research received no external funding.

Acknowledgments: Comments from J.A. Simonetti on an earlier version of this manuscript helped us to clarify our initial ideas and to focus on the analysis. Comments from two anonymous reviewers improved the manuscript. F.E.F. acknowledges the support of ANID/PIA/ACT192027 project.

Conflicts of Interest: The authors declare no conflict of interest.

\section{References}

1. Humphreys, A.M.; Govaerts, R.; Ficinski, S.Z.; Lughadha, N.E.; Vorontsova, M.S. Global dataset shows geography and life form predict modern plant extinction and rediscovery. Nat. Ecol. Evol. 2019, 3, $1043-1047$. [CrossRef]

2. Balmford, A.; Bennun, L.; Ten Brink, B.; Cooper, D.; Cote, I.M.; Crane, P.; Dobson, A.; Dudley, N.; Dutton, I.; Green, R.E.; et al. The convention on biological diversity's 2010 target. Science 2005, 307, 212-213. [CrossRef]

3. Hooper, D.U.; Adair, E.C.; Cardinale, B.J.; Byrnes, J.E.K.; Hungate, B.A.; Matulich, K.L.; Gonzalez, A.; Duffy, J.E.; Gamfeldt, L.; O'Connor, M.I. A global synthesis reveals biodiversity loss as a major driver of ecosystem change. Nature 2012, 486, 105-108. [CrossRef]

4. Newbold, T.; Hudson, L.N.; Hill, S.L.L.; Contu, S.; Lysenko, I.; Senior, R.A.; Borger, L.; Bennett, D.J.; Choimes, A.; Collen, B.; et al. Global effects of land use on local terrestrial biodiversity. Nature 2015, 520, 45-50. [CrossRef]

5. Cardinale, B.J.; Duffy, J.E.; Gonzalez, A.; Hooper, D.U.; Perrings, C.; Venail, P.; Narwani, A.; Mace, G.M.; Tilman, D.; Wardle, D.A.; et al. Biodiversity loss and its impact on humanity. Nature 2012, 486, 59-67. [CrossRef]

6. Butchart, S.H.M.; Walpole, M.; Collen, B.; Van Strien, A.; Scharlemann, J.P.W.; Almond, R.E.A.; Baillie, J.E.M.; Bomhard, B.; Brown, C.; Bruno, J.; et al. Global Biodiversity: Indicators of Recent Declines. Science 2010, 328, 1164-1168. [CrossRef]

7. Rodrigues, A.S.L.; Andelman, S.J.; Bakarr, M.I.; Boitani, L.; Brooks, T.M.; Cowling, R.M.; Fishpool, L.D.C.; da Fonseca, G.A.B.; Gaston, K.J.; Hoffmann, M.; et al. Effectiveness of the global protected area network in representing species diversity. Nature 2004, 428, 640-643. [CrossRef]

8. Watson, J.E.M.; Dudley, N.; Segan, D.B.; Hockings, M. The performance and potential of protected areas. Nature 2014, 515, 67-73. [CrossRef]

9. Carranza, T.; Balmford, A.; Kapos, V.; Manica, A. Protected area effectiveness in reducing conversion in a rapidly vanishing ecosystem: The Brazilian Cerrado. Conserv. Lett. 2014, 7, 216-223. [CrossRef] 
10. Armesto, J.J.; Rozzi, R.; Smith-Ramirez, C.; Arroyo, M.T.K. Conservation targets in South American temperate forests. Science 1998, 282, 1271-1272. [CrossRef]

11. Durán, A.P.; Rauch, J.; Gaston, K.J. Global spatial coincidence between protected areas and metal mining activities. Biol. Conserv. 2013, 160, 272-278. [CrossRef]

12. Fontúrbel, F.E.; Tarifa, T. Can a habitat specialist survive urbanization? the case of the viscacha (Lagidium viscacia, Chinchillidae). Urban Ecosyst. 2014, 17, 163-172. [CrossRef]

13. Sanderson, E.W.; Walston, J.; Robinson, J.G. From bottleneck to breakthrough: Urbanization and the future of biodiversity conservation. Bioscience 2018, 68, 412-426. [CrossRef]

14. Mcdonald, R.I.; Kareiva, P.; Formana, R.T.T. The implications of current and future urbanization for global protected areas and biodiversity conservation. Biol. Conserv. 2008, 141, 1695-1703. [CrossRef]

15. Acosta, C.A. International conservation education. Conserv. Biol. 2000, 14, 924. [CrossRef]

16. Caro, T.M.; Pelkey, N.; Grigione, M. Effects of conservation biology education on attitudes toward nature. Conserv. Biol. 1994, 8, 846-852. [CrossRef]

17. Strauss, B. Education in the real world. Conserv. Biol. 1995, 9, 1346-1348. [CrossRef]

18. van Weelie, D.; Wals, A.E.J. Making biodiversity meaningful through environmental education. Int. J. Sci. Educ. 2002, 24, 1143-1156. [CrossRef]

19. Kassas, M. Environmental education: Biodiversity. Environmentalist 2002, 22, 345-351. [CrossRef]

20. Aznar-Diaz, I.; Hinojo-Lucena, F.J.; Caceres-Reche, M.P.; Trujillo-Torres, J.M.; Romero-Rodriguez, J.M. Environmental attitudes in trainee teachers in primary education. The future of biodiversity preservation and environmental pollution. Int. J. Env. Res. Pub. Health 2019, 16, 362. [CrossRef]

21. Navarro-Perez, M.; Tidball, K. Challenges of Biodiversity Education: A Review of Education Strategies for Biodiversity Education. Int. Electron. J. Environ. Educ. 2012, 2, 13-30.

22. Frost, D.R. Amphibian Species of the World: An Online Reference. Version 6.0. Available online: http://research.amnh.org/herpetology/amphibia/index.html (accessed on 22 October 2017).

23. Wilson, D.; Reeder, D. Mammal Species of the World. A Taxonomic and Geographic Reference; Johns Hopkins University Press: Baltimore, MD, USA, 2005.

24. Frodin, D. Guide to Standard Floras of the World. An Annotated, Geographically Arranged Systematic Bibliography of the Principal Floras, Enumerations, Checklists and Chorological Atlases of Different Areas; Cambridge University Press: Cambridge, UK, 2010.

25. Pautasso, M. Scale dependence of the correlation between human population presence and vertebrate and plant species richness. Ecol. Lett. 2007, 10, 16-24. [CrossRef]

26. Kier, G.; Kreft, H.; Lee, T.M.; Jetz, W.; Ibisch, P.L.; Nowicki, C.; Mutke, J.; Barthlott, W. A global assessment of endemism and species richness across island and mainland regions. Proc. Natl. Acad. Sci. USA 2009, 106, 9322-9327. [CrossRef] [PubMed]

27. Aronson, M.F.J.; La Sorte, F.A.; Nilon, C.H.; Katti, M.; Goddard, M.A.; Lepczyk, C.A.; Warren, P.S.; Williams, N.S.G.; Cilliers, S.; Clarkson, B.; et al. A global analysis of the impacts of urbanization on bird and plant diversity reveals key anthropogenic drivers. Proc. R. Soc. B Boil. Sci. 2014, 281, 20133330. [CrossRef]

28. French, S.S.; Webb, A.C.; Hudson, S.B.; Virgin, E.E. Town and country reptiles: A review of reptilian responses to urbanization. Integr. Comp. Biol. 2018, 58, 948-966. [CrossRef] [PubMed]

29. Schmidt, C.; Domaratzki, M.; Kinnunen, R.P.; Bowman, J.; Garroway, C.J. Continent-wide effects of urbanization on bird and mammal genetic diversity. Proc. R. Soc. B Boil. Sci. 2020, 287, 20192497. [CrossRef]

30. Kinzig, A.P.; Warren, P.; Martin, C.; Hope, D.; Katti, M. The effects of human socioeconomic status and cultural characteristics on urban patterns of biodiversity. Ecol. Soc. 2005, 10, 23. [CrossRef]

31. Hope, D.; Gries, C.; Zhu, W.; Fagan, W.F.; Redman, C.L.; Grimm, N.B.; Nelson, A.L.; Martin, C.; Kinzig, A. Socioeconomics drive urban plant diversity. In Urban Ecology; Marzluff, J.M., Shulenberger, E., Endlicher, W., Alberti, M., Bradley, G., Ryan, C., Simon, U., ZumBrunnen, C., Eds.; Springer: Boston, MA, USA, 2008; pp. 339-347.

32. Chape, S.; Harrison, J.; Spalding, M.; Lysenko, I. Measuring the extent and effectiveness of protected areas as an indicator for meeting global biodiversity targets. Philos. Trans. R. Soc. B Biol. Sci. 2005, 360, 443-455. [CrossRef]

33. Zuur, A.; Ieno, E.N.; Walker, N.; Saveliev, A.A.; Smith, G.M. Mixed Effects Models and Extensions in Ecology with R; Springer: New York, NY, USA, 2009. 
34. Halekoh, U.; Højsgaard, S. A Kenward-Roger approximation and parametric bootstrap methods for tests in linear mixed models-The R Package pbkrtest. J. Stat. Softw. 2014, 59, 1-30. [CrossRef]

35. Burnham, K.P.; Anderson, D.R. Model Selection and Multimodel Inference: A Practical Information-Theoretic Approach, 2nd ed.; Springer: New York, NY, USA, 2004; p. 515.

36. R Development Core Team. R: A Language and Environment for Statistical Computing, Reference Index Version 3.5.1.; Foundation for Statistical Computing: Vienna, Austria, 2018.

37. Wood, S.; Scheipl, F. gamm4: Generalized Additive Mixed Models Using Mgcv and lme4. R Package Version 0.2-3. 2014. Available online: http://CRAN.R-project.org/package=gamm4 (accessed on 22 October 2017).

38. Bates, D.; Maechler, M.; Bolker, B. lme4: Linear Mixed-Effects Models Using S4 Classes. R Package Version 0.999375-39. 2013. Available online: http://CRAN.R-project.org/package=lme4 (accessed on 22 October 2017).

39. Kusnetzova, A.; Brockhoff, P.B.; Haubo, R. lmerTest: Test in Linear Mixed Effects Models. R Package Version 2.0-25. 2015. Available online: http://CRAN.R-project.org/package=lmerTest (accessed on 22 October 2017).

40. Bartoń, K. MuMIn: Multi-Model Inference. R Package Version 1.42.1. 2018. Available online: https://CRAN.R-project.org/package=MuMIn (accessed on 22 October 2017).

41. Pyke, C.R.; Alagona, P.S.; Goldstein, N.; Bierwagen, B.; Merrick, J.; Rosenberg, H.; Gallo, J. A plan for outreach: Defining the scope of conservation education. Conserv. Biol. 1999, 13, 1238-1239. [CrossRef]

42. Duarte, M.; Guerrero, P.C.; Carvallo, G.O.; Bustamante, R.O. Conservation network design for endemic cacti under taxonomic uncertainty. Biol. Conserv. 2014, 176, 236-242. [CrossRef]

43. Medel, R.; González-Browne, C.; Fontúrbel, F.E. Pollination in the Chilean Mediterranean-type ecosystem: A review of current advances and pending tasks. Plant Biol. 2018, 20, 89-99. [CrossRef]

44. Peh, K.S.H.; Sodhi, N.S.; De Jong, J.; Sekercioglu, C.H.; Yap, C.A.M.; Lim, S.L.H. Conservation value of degraded habitats for forest birds in southern Peninsular Malaysia. Divers. Distrib. 2006, 12, 572-581. [CrossRef]

45. Barlow, J.; Mestre, L.A.M.; Gardner, T.A.; Peres, C.A. The value of primary, secondary and plantation forests for Amazonian birds. Biol. Conserv. 2007, 136, 212-231. [CrossRef]

46. Bohada-Murillo, M.; Castano-Villa, G.J.; Fontúrbel, F.E. The effects of forestry and agroforestry plantations on bird diversity: A global synthesis. Land Degrad. Dev. 2020, 31, 646-654. [CrossRef]

47. Margules, C.R.; Pressey, R.L. Systematic conservation planning. Nature 2000, 405, 243-253. [CrossRef]

48. Jenkins, C.N.; Pimm, S.L.; Joppa, L.N. Global patterns of terrestrial vertebrate diversity and conservation. Proc. Natl. Acad. Sci. USA 2013, 110, E2602-E2610. [CrossRef]

49. Pimm, S.L.; Jenkins, C.N.; Abell, R.; Brooks, T.M.; Gittleman, J.L.; Joppa, L.N.; Raven, P.H.; Roberts, C.M.; Sexton, J.O. The biodiversity of species and their rates of extinction, distribution, and protection. Science 2014, 344, a1246752. [CrossRef]

50. Hamer, A.J.; McDonnell, M.J. The response of herpetofauna to urbanization: Inferring patterns of persistence from wildlife databases. Austral Ecol. 2010, 35, 568-580. [CrossRef]

51. Goddard, M.A.; Dougill, A.J.; Benton, T.G. Scaling up from gardens: Biodiversity conservation in urban environments. Trends Ecol. Evol. 2010, 25, 90-98. [CrossRef]

52. Hahs, A.K.; McDonnell, M.J.; McCarthy, M.A.; Vesk, P.A.; Corlett, R.T.; Norton, B.A.; Clemants, S.E.; Duncan, R.P.; Thompson, K.; Schwartz, M.W.; et al. A global synthesis of plant extinction rates in urban areas. Ecol. Lett. 2009, 12, 1165-1173. [CrossRef]

53. McKinney, M.L. Effects of urbanization on species richness: A review of plants and animals. Urban Ecosyst. 2008, 11, 161-176. [CrossRef]

54. Dirzo, R.; Young, H.S.; Galetti, M.; Ceballos, G.; Isaac, N.J.B.; Collen, B. Defaunation in the Anthropocene. Science 2014, 345, 401-406. [CrossRef]

55. Leverington, F.; Costa, K.L.; Pavese, H.; Lisle, A.; Hockings, M. A global analysis of protected area management effectiveness. Environ. Manag. 2010, 46, 685-698. [CrossRef]

Publisher's Note: MDPI stays neutral with regard to jurisdictional claims in published maps and institutional affiliations. 